\title{
Surface energy balance, melt and sublimation at Neumayer Station, East Antarctica
}

\author{
MICHIEL VAN DEN BROEKE ${ }^{1 *}$, GERT KÖNIG-LANGLO², GHISLAIN PICARD ${ }^{3}$, \\ PETER KUIPERS MUNNEKE ${ }^{1}$ and JAN LENAERTS ${ }^{1}$ \\ ${ }^{1}$ Utrecht University, Institute for Marine and Atmospheric Research Utrecht (IMAU), The Netherlands \\ ${ }^{2}$ Alfred Wegener Institute for Marine and Polar Research (AWI), Bremerhaven, Germany \\ ${ }^{3}$ Laboratoire de Glaciologie et de Géophysique de l'Environnement (LGGE), Grenoble, France \\ *m.r.vandenbroeke@uu.nl
}

\begin{abstract}
A surface energy balance model is forced by 13 years of high-quality hourly observations from the Antarctic coastal station Neumayer. The model accurately reproduces observed surface temperatures. Surface sublimation is significant in summer, when absorbed solar radiation heats the surface. Including a first order estimate of snowdrift sublimation in the calculation more than triples the total sublimation, removing $19 \%$ of the solid precipitation, indicating that snowdrift sublimation is potentially important for the mass balance of Antarctic ice shelves. Surface melt occurs at Neumayer in all summers, but all the meltwater refreezes. In two-thirds of the cases, the refreezing is quasi-instantaneous (within the model timestep of $6 \mathrm{~min}$ ), so that no liquid water remains in the snow. For all other events, the occurrence of liquid water in the snowpack at Neumayer agrees well with satellite-based liquid water detection.
\end{abstract}

Received 31 May 2009, accepted 17 August 2009

Key words: solar radiation, snowpack, surface temperatures

\section{Introduction}

The specific surface mass balance of a snow/ice surface (SSMB, units $\mathrm{kg} \mathrm{m}^{-2} \mathrm{yr}^{-1}$ ) can be written as the annual sum of precipitation (PR), surface sublimation (SU), meltwater runoff $(\mathrm{RU})$ and erosion $\left(\mathrm{ER}_{\mathrm{ds}}\right)$ and sublimation of drifting snow particles $\left(\mathrm{SU}_{\mathrm{ds}}\right)$ :

$$
\mathrm{SSMB}=\int_{\text {year }} \mathrm{dt}\left(\mathrm{PR}-\mathrm{SU}-\mathrm{RU}-\mathrm{ER}_{\mathrm{ds}}-\mathrm{SU} \mathrm{ds}\right)
$$

Although of secondary importance for the area-integrated surface mass balance of the Antarctic ice sheet (Van de Berg et al. 2006), sublimation and melting/runoff may exert a large influence on the local mass balance (Frezzotti et al. 2004). The disintegration of ice shelves in the Antarctic Peninsula has been - in part - ascribed to enhanced summer melting (Scambos et al. 2003, Sergienko \& Macayeal 2005, Van den Broeke 2005), following a rapid regional warming (Morris \& Vaughan 2003, Vaughan et al. 2003). In combination with snowdrift erosion, sublimation is thought to be responsible for the formation of blue ice areas (Takahashi et al. 1988, Van den Broeke et al. 2006). Moreover, melting and sublimation both influence the isotope signal in ice cores (Masson-Delmotte et al. 2008). Snowdrift sublimation cools the air and enhances katabatic winds (Gosink 1989) while melt disturbs the passive microwave signal that is used as a proxy for accumulation (Magand et al. 2008). Both melt and sublimation are expected to increase in a warming climate, so a good understanding of these processes is required to more accurately predict the future mass balance of the Antarctic ice sheet.

Several techniques exist to quantify melting and sublimation on the Antarctic ice sheet. The presence of liquid water in the snowpack can be detected by passive and active microwave sensors onboard satellites (Zwally \& Fiegles 1994, Fahnestock et al. 2002). Picard \& Fily (2006) and Picard et al. (2007) present 26-year (1981-2006) climatology of Antarctic melting using data from the Scanning Multichannel Microwave Radiometer (SMMR) and three Special Sensor Microwave Imager (SSM/I). The average period during which liquid water is detected in the snowpack shows large interannual variability, but ranges on average from 1-10 days on the Ross and Filchner-Ronne ice shelves, 10-30 days on the ice shelves fringing the more northerly coasts of East Antarctica and Marie Byrd Land in West Antarctica, and 30-90 days for ice shelves in the Antarctic Peninsula.

Alternatively, regional atmospheric climate models can be used to assess the SSMB components. Van den Broeke et al. (2006) used output of the RACMO2/ANT model to calculate annual meltwater production and surface/snowdrift sublimation in Antarctica $\left(\mathrm{kg} \mathrm{m}^{-2} \mathrm{yr}^{-1}\right.$, Fig. 1). The model predicts melting to occur primarily on the low-lying ice shelves, with annual mean meltwater fluxes ranging from $0-20 \mathrm{~kg} \mathrm{~m}^{-2} \mathrm{yr}^{-1}$ on the Ross and Filchner-Ronne ice shelves, up to $100 \mathrm{~kg} \mathrm{~m}^{-2} \mathrm{yr}^{-1}$ on the northernmost East Antarctic ice shelves and in excess of $400 \mathrm{~kg} \mathrm{~m}^{-2} \mathrm{yr}^{-1}$ on ice shelves in the Antarctic Peninsula (Fig. 1a). Melt is predicted to occur up to elevations 

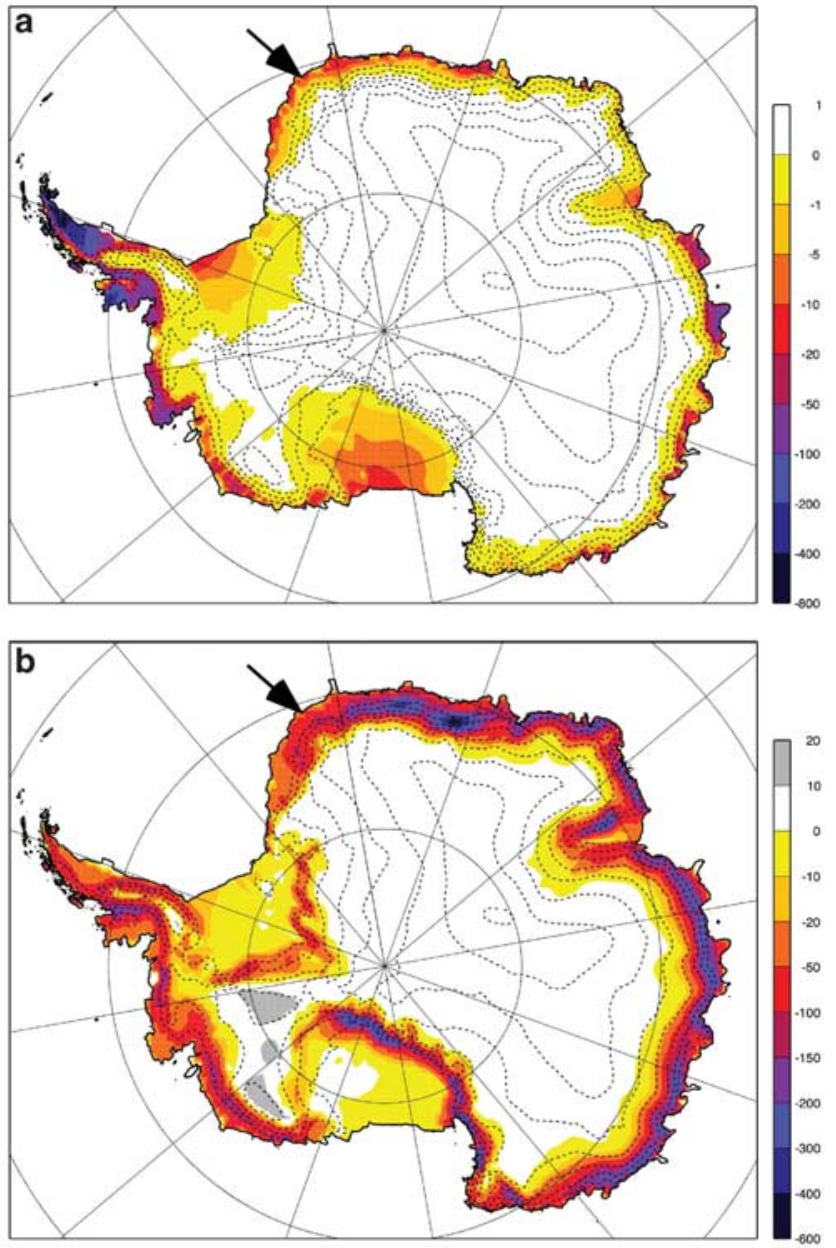

Fig. 1. a. Annual melt, and b. total (surface and snowdrift) sublimation in $\mathrm{kg} \mathrm{m}^{-2} \mathrm{yr}^{-1}$ from a regional atmospheric climate model (RACMO2/ANT). Adapted from Van den Broeke et al. (2006). Arrows indicate the location of Neumayer Station, dashed lines $500 \mathrm{~m}$ elevation contours.

of $1500-2000 \mathrm{~m}$, in accordance with recent reports (Nghiem et al. 2008). Modelled sublimation (the sum of surface and snowdrift sublimation, Fig. 1b) is largely controlled by temperature, and peaks at lower elevations during summer with values regionally also in excess of $400 \mathrm{~kg} \mathrm{~m}^{-2} \mathrm{yr}^{-1}$.

Both satellite and model data require validation, but in situ melt rate and sublimation of Antarctic snow are difficult to measure. Meltwater readily penetrates the porous firn to refreeze at some depth, and while surface sublimation can be measured using evaporation pans (Fujii 1979) or eddy correlation sensors, these instruments are not suitable for year-round operation. In this paper we use 13 years of hourly observations from Neumayer station (coastal East Antarctica) to drive a model that calculates the full energy balance, including melt and surface sublimation, and estimates snowdrift sublimation.

\section{Methods}

\section{Surface energy balance model}

Equation (2) describes the energy balance for a 'skin' surface layer without heat capacity, i.e. all terms are evaluated at the surface and are defined positive when directed towards the surface:

$$
\begin{aligned}
\mathrm{M} & =\mathrm{SW}_{\text {in }}+\mathrm{SW}_{\text {out }}+\mathrm{LW}_{\text {in }}+\mathrm{LW}_{\text {out }}+\mathrm{SHF}+\mathrm{LHF}+\mathrm{G}_{\mathrm{s}} \\
& =\mathrm{SW}_{\text {net }}+\mathrm{LW}_{\text {net }}+\mathrm{SHF}+\mathrm{LHF}+\mathrm{G}_{\mathrm{s}} \\
& =\mathrm{R}_{\text {net }}+\mathrm{SHF}+\mathrm{LHF}+\mathrm{G}_{\mathrm{s}}
\end{aligned}
$$

where $\mathrm{M}$ is melt energy $(M=0$ if the surface temperature $\left.T_{\mathrm{s}}<273.15 \mathrm{~K}\right), \mathrm{SW}_{\text {in }}$ and $\mathrm{SW}_{\text {out }}$ are incoming and reflected shortwave radiation fluxes, $\mathrm{LW}_{\mathrm{in}}$ and $\mathrm{LW}_{\text {out }}$ are incoming and emitted longwave radiation fluxes, SHF and LHF are the turbulent fluxes of sensible and latent heat and $\mathrm{G}_{\mathrm{s}}$ is the subsurface conductive heat flux. Penetration of shortwave radiation and heat added to the surface by precipitation are neglected.

To solve Eq. (2), near surface observations are fed into a 1D surface energy balance (SEB) model that searches iteratively for a surface temperature $T_{\mathrm{s}}$ for which Eq. (2) is valid. The SEB model has an atmospheric part and a subsurface part. In the atmospheric part, $\mathrm{SW}_{\text {in }}, \mathrm{SW}_{\text {out }}$ and $\mathrm{LW}_{\text {in }}$ are taken from (corrected) observations. Next, SHF and LHF are calculated using the bulk method, the vertically integrated version of the flux-profile relations. The bulk method uses single-level wind speed, temperature and relative humidity data in combination with modelled $T_{\mathrm{s}}$ to determine the turbulent velocity $\left(\mathrm{u}_{*}\right)$, temperature $\left(\theta_{*}\right)$ and humidity $\left(\theta_{*}\right)$ scales. These are then used to calculate the turbulent fluxes following:

$$
\begin{aligned}
& \mathrm{SHF}=\rho \mathrm{c}_{\mathrm{p}} \mathrm{u}_{*} \theta_{*} \\
& \mathrm{LHF}=\rho \mathrm{L}_{\mathrm{s}} \mathrm{u}_{*} \mathrm{q}_{*}
\end{aligned}
$$

where $\rho=$ air density, $c_{p}=$ specific heat of air at constant pressure and $\mathrm{L}_{\mathrm{s}}=$ latent heat of sublimation. Also required for the calculation of the turbulent fluxes is the surface aerodynamic roughness length $\mathrm{z}_{0}$, which is calculated using 2 and $10 \mathrm{~m}$ wind speed. As no clear seasonal cycle was found, a constant value of $\log \left(\mathrm{z}_{0}\right)=-3.5$ was adopted for no-drift conditions (König-Langlo 1985). The roughness lengths for heat $\mathrm{z}_{\mathrm{h}}$ and moisture $\mathrm{z}_{\mathrm{q}}$ are calculated as a function of $\mathrm{u} *$ and $\mathrm{z}_{0}$ using the expressions of Andreas (1987). A direct comparison with eddy correlation measurements is not possible, but previous studies have shown that the bulk method performs well in Antarctica (Van den Broeke et al. 2004b, 2005a).

The subsurface part of the model calculates temperature profiles and subsurface heat flux (G) in $4 \mathrm{~cm}$ thick snow layers for the upper $20 \mathrm{~m}$ of the snowpack, below which $\mathrm{G}$ is assumed to vanish. Heat conductivity is made a function of snow density, following Anderson (1976), and surface snow density is set to $420 \mathrm{~kg} \mathrm{~m}^{-3}$ and kept constant with depth. The model tracks meltwater that is formed at the 


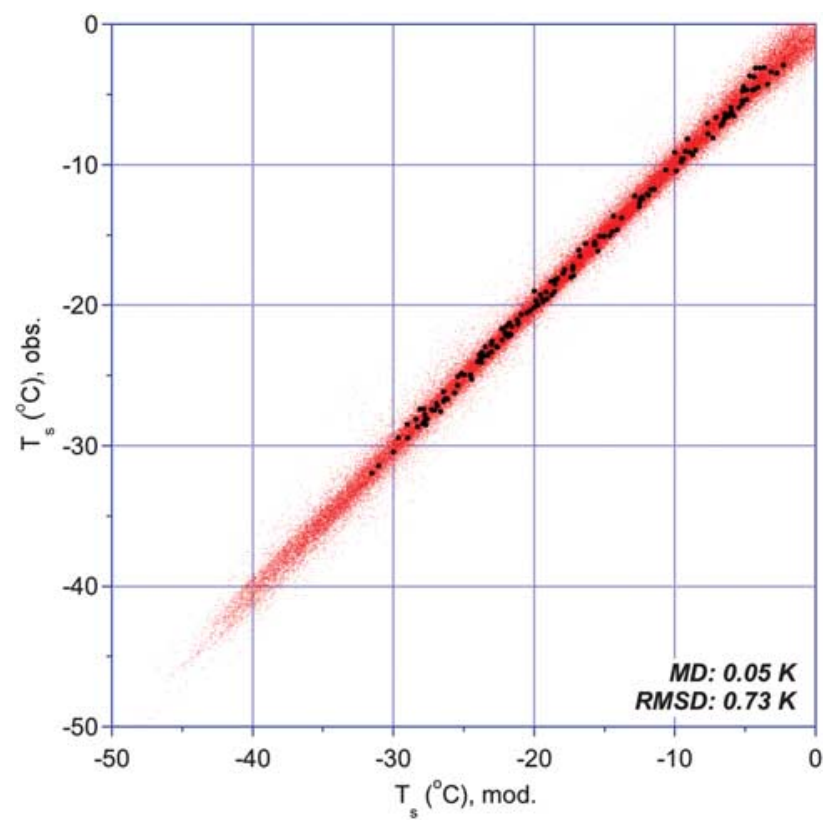

Fig. 2. Comparison of observed and modelled surface temperature, for hourly means (red dots) and monthly means (black dots).

surface and lets it refreeze in the snowpack using a bucket method, i.e. vertical transport of meltwater is assumed quasi-instantaneous (within the time step of six minutes). To allow liquid water to remain in the upper snow layers, a capillary meltwater retention of maximum $2 \%$ of the available pore space is prescribed.

\section{Meteorological input data}

For this paper we use 13 years of hourly mean meteorological data (1 January 1995-31 December 2007) collected at the German Antarctic station Neumayer $\left(70^{\circ} 39^{\prime} \mathrm{S}, 8^{\circ} 15^{\prime} \mathrm{W}, 40 \mathrm{~m}\right.$ a.s.l., indicated by the arrows in Fig. 1). Neumayer is situated on Ekströmisen, an ice shelf

Table I. Annual means at Neumayer for the standard run (1995-2007).

Pressure $(\mathrm{hPa})$ 982

$2 \mathrm{~m}$ temperature $\left({ }^{\circ} \mathrm{C}\right)$

Surface temperature $\left({ }^{\circ} \mathrm{C}\right)$

$-16.0$

Relative humidity (\%)

$2 \mathrm{~m}$ specific humidity $\left(\mathrm{g} \mathrm{kg}^{-1}\right)$

$10 \mathrm{~m}$ wind speed $\left(\mathrm{m} \mathrm{s}^{-1}\right)$

Surface albedo

$\mathrm{SW}_{\text {net }}\left(\mathrm{W} \mathrm{m}^{-2}\right)$

$\mathrm{LW}_{\text {net }}\left(\mathrm{W} \mathrm{m}^{-2}\right)$

$\mathrm{R}_{\text {net }}\left(\mathrm{W} \mathrm{m}^{-2}\right)$

$\mathrm{u} *\left(\mathrm{~m} \mathrm{~s}^{-1}\right)$

$\theta_{*}(\mathrm{~K})$

$\theta_{*}\left(10^{-3} \mathrm{~g} \mathrm{~kg}^{-1}\right)$

$\mathrm{SHF}\left(\mathrm{W} \mathrm{m}^{-2}\right)$

LHF $\left(\mathrm{W} \mathrm{m}^{-2}\right)$

$\mathrm{G}\left(\mathrm{W} \mathrm{m}^{-2}\right)$

$\mathrm{M}\left(\mathrm{W} \mathrm{m}^{-2}\right)$ fringing the East Antarctic Ice Sheet in the north-eastern Weddell Sea. The radiation measurements at Neumayer comply with the standard of the Baseline Surface Radiation Network (BSRN). Furthermore we use $10 \mathrm{~m}$ wind speed
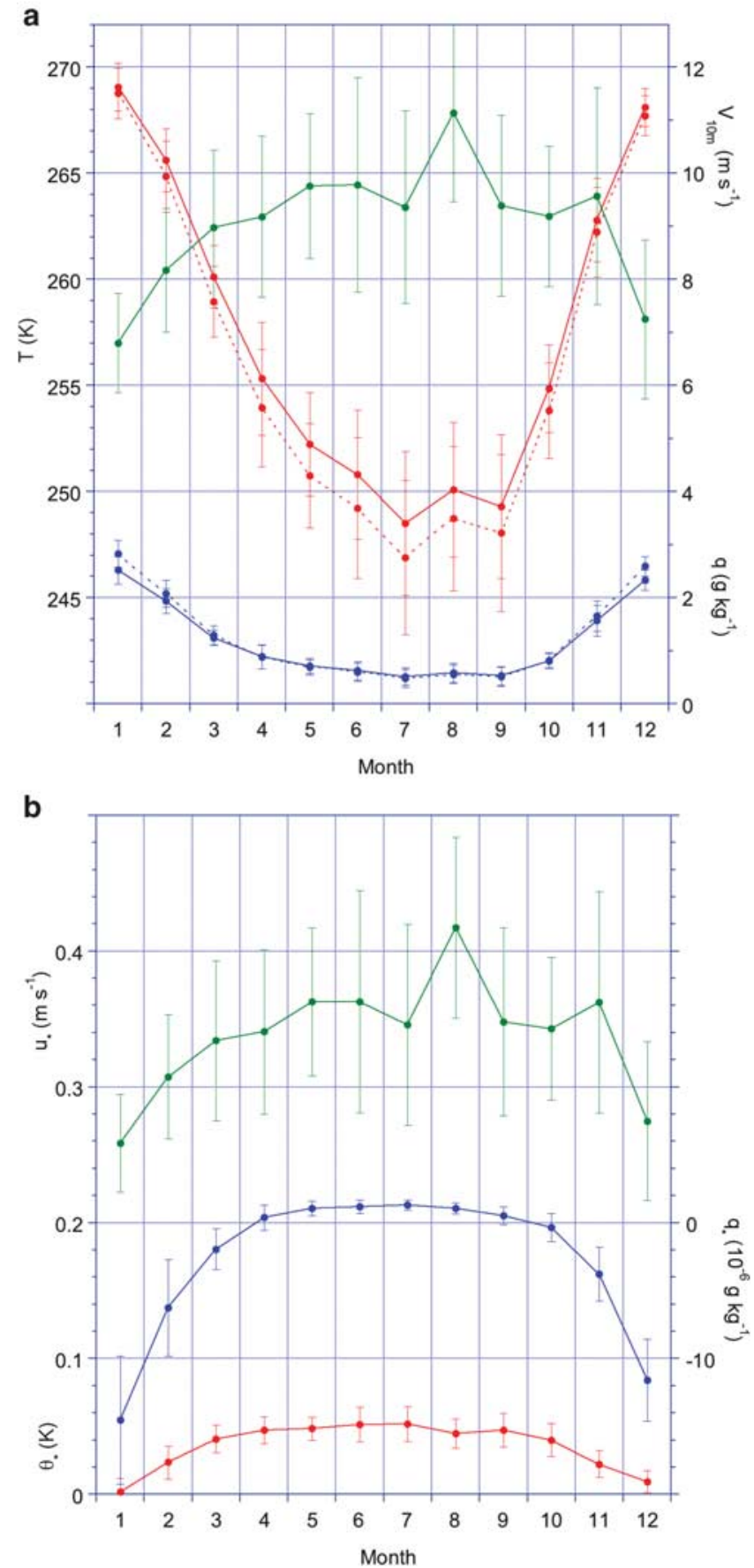

Fig. 3. Average (1994-2006) seasonal cycle of a. $2 \mathrm{~m}$ (solid lines) and surface (dashed lines) temperature/specific humidity and $10 \mathrm{~m}$ wind speed, and $\mathbf{b}$. turbulent scales of velocity $\left(\mathrm{u}_{*}\right)$, temperature $\left(\theta_{*}\right)$ and specific moisture $\left(\theta_{*}\right)$. Error bars indicate standard deviation of the monthly means (1995-2007). 
and $2 \mathrm{~m}$ temperature/relative humidity measurements to calculate the turbulent fluxes of sensible and latent heat. Relative humidity measurements are corrected along the lines of Anderson (1994), while shortwave radiative fluxes are treated according to the method described by Van den Broeke et al. (2004a). The radiation data of Neumayer are accessible through the Pangea database (www.pangaea.de).

\section{Results: surface energy balance}

\section{Validation of modelled surface temperature}

The most direct way to validate the SEB model is to compare modelled and observed hourly mean surface temperature $T_{\mathrm{s}}$, where 'observed' $T_{s}$ is derived from $L W_{\text {out }}$, assuming the surface to have unit longwave emissivity. Figure 2 shows the result. Agreement for hourly (monthly) values is very good, with a mean difference $(\mathrm{MD})$ of $0.05 \mathrm{~K}(0.04 \mathrm{~K})$ and a root mean squared difference (RMSD) of $0.73 \mathrm{~K}(0.45 \mathrm{~K})$. This shows that all relevant processes are included and that the modelled SEB components are robust.

\section{Seasonal cycle of surface layer climate and turbulent scales}

Table I shows annual means and Fig. 3a the average seasonal cycle of $10 \mathrm{~m}$ wind speed $\left(\mathrm{V}_{10 \mathrm{~m}}\right)$, temperature at $2 \mathrm{~m}$ and the surface $\left(\mathrm{T}_{2 \mathrm{~m}}, \mathrm{~T}_{\mathrm{a}}\right)$ and specific humidity at $2 \mathrm{~m}$ and the surface $\left(\mathrm{q}_{2 \mathrm{~m}} \mathrm{q}_{\mathrm{s}}\right)$. Owing to the proximity of the Weddell Sea, which is covered by sea ice for most of the year, Neumayer is relatively cold (König-Langlo et al. 1998) compared to coastal stations further east. The high wind speeds are caused by frequent passages of lowpressure areas in the southern Atlantic Ocean, forcing strong easterlies over the coastal ice shelves of Dronning Maud Land. The seasonal cycle of wind speed shows a clear wintertime maximum, with monthly mean $10 \mathrm{~m}$ wind speed close to or in excess of $10 \mathrm{~m} \mathrm{~s}^{-1}$ (Fig. 3a). Because the ice shelf is almost flat, this is likely caused by enhanced depression activity and the outflow of cold air that piles up on the shelf as a result of enhanced katabatic activity further inland rather than local katabatic forcing.

Table I shows annual means and Fig. $3 b$ the seasonal cycle of turbulent scales of velocity $\left(\mathrm{u}_{*}\right)$, temperature $\left(\theta_{*}\right)$ and moisture $(\theta *)$. Because of the high wind speed, stability effects are modest and the seasonal cycle of friction velocity $\mathrm{u} *$ mirrors variations in $10 \mathrm{~m}$ wind speed. The occasional daytime convection in summer is not sufficient to reverse the monthly mean near-surface temperature gradient (Fig. 3a), although stratification is considerably weaker than in winter. This is reflected in the magnitude of the turbulent temperature scale $\theta_{*}$, which peaks in winter and becomes small in summer (Fig. 3b).

At Neumayer, relative humidity has a weak seasonal cycle (not shown), with maximum monthly mean values $(\sim 96 \%)$ in winter and minimum values $(\sim 88 \%)$ in
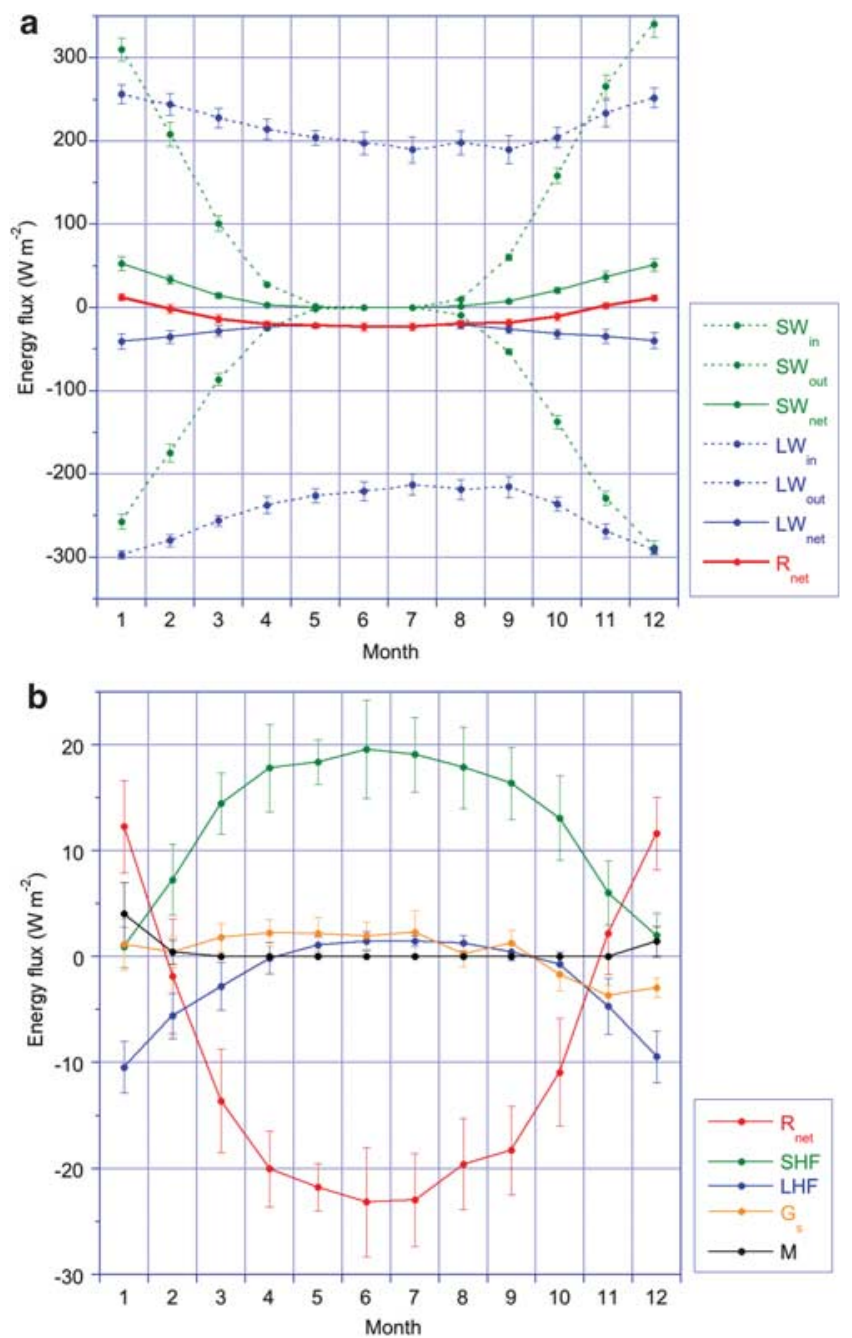

Fig. 4. Average (1994-2006) seasonal cycle of a. radiation components, and b. surface energy balance components. Error bars indicate standard deviation of the monthly means (1995-2007).

summer. That is why specific humidity in first order follows temperature (Fig. 3a). In contrast to temperature, the specific humidity gradient changes sign from weakly positive (deposition) in winter to negative (sublimation) in summer, which is reflected in the seasonal cycle of the turbulent moisture scale $\theta *$ (Fig. 3b).

\section{Seasonal cycle of surface energy balance components}

Table I shows annual means and Fig. 4a the average seasonal cycle of radiation components $\mathrm{SW}_{\text {net }}, \mathrm{LW}_{\text {net }}$ and $\mathrm{R}_{\text {net }}$. As is typical for an Antarctic site with high albedo (0.87) and little melt, annual mean $\mathrm{R}_{\text {net }}$ is negative $\left(-10.5 \mathrm{~W} \mathrm{~m}^{-2}\right)$; only in the summer months December and January, when sufficient solar radiation is absorbed at the snow surface, does $R_{\text {net }}$ become positive; $\mathrm{R}_{\mathrm{net}} \sim 0$ during the transition months February and November. 

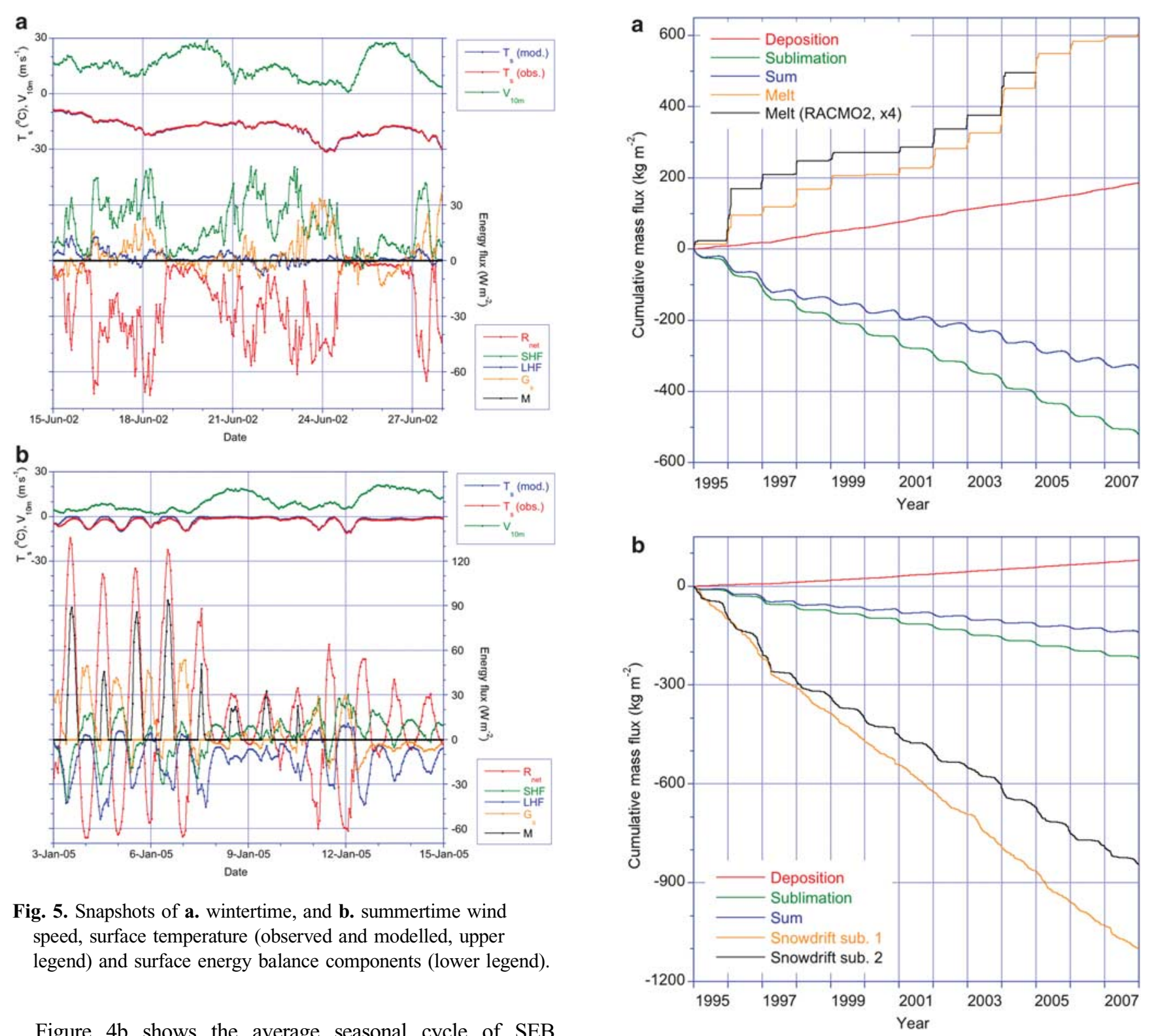

Figure $4 \mathrm{~b}$ shows the average seasonal cycle of SEB components. During winter, the radiative heat loss is compensated in first order by SHF and in second order by $\mathrm{G}_{\mathrm{s}}$ and LHF. The transport of sensible heat towards the surface is primarily driven by the radiative cooling, which maintains the required temperature gradient between surface and atmosphere, and persistent winds, which generate the wind shear necessary to overcome the static stability in the SL.

The most important difference between Neumayer and inland katabatic wind sites is that there is no coupling between cooling and wind speed, as is the case with katabatic flow. During December and January, $R_{\text {net }}$ becomes positive which is compensated mainly by sublimation (LHF) and in second order by melting (M) and the subsurface heat flux. The seasonal cycle in sublimation is comparable to that observed at Halley, a station situated on the Brunt Ice Shelf further west (King et al. 2001).

Fig. 6. Cumulative surface mass fluxes at Neumayer for a. the control run (no snowdrift allowed), including melt from RACMO2/ANT (black line), and b. the snowdrift run. In the snowdrift run, melting remained unchanged and is not shown.

\section{SEB snapshots}

To illustrate in more detail the conditions that are favourable for sublimation and melting at Neumayer, Fig. 5 shows wind speed, observed and modelled surface temperature $T_{S}$ and SEB components at hourly resolution for a typical $\sim$ twoweek period in winter (a) and summer (b). During the winter episode (Fig. 5a), surface temperature $\mathrm{T}_{\mathrm{s}}$ varies between -10 and $-30^{\circ} \mathrm{C}$. Under these cold conditions, moisture concentrations/gradients are very low and LHF is small, typically $<10 \mathrm{~W} \mathrm{~m}^{-2}$. Two events with wind speeds as high as $30 \mathrm{~m} \mathrm{~s}^{-1}$ signify the passing of a low-pressure system north of 
Neumayer. During these events, clouds limit the longwave radiation loss, which in turn limits the near-surface temperature gradient, causing the other fluxes to be small as well.

During clear-sky conditions in winter, $\mathrm{R}_{\text {net }}$ decreases to values as low as $-70 \mathrm{~W} \mathrm{~m}^{-2}$. When winds are sufficiently strong, the radiative energy loss is compensated by SHF (e.g. 21 June); in the absence of strong winds, however, SHF is not large enough to compensate the radiative heat loss and as a result $\mathrm{T}_{\mathrm{s}}$ decreases rapidly (e.g. 23 June). In combination with subsurface snow layers that are still relatively warm, this enhances $G_{s}$, which quickly becomes comparable in magnitude to SHF.

The summertime SEB is considerably more complex, with a pronounced daily cycle in all components (Fig. 5b). Cloudy conditions are often associated with the passage of cyclones, enhanced wind speeds $\left(\sim 20 \mathrm{~m} \mathrm{~s}^{-1}\right)$ and a strongly reduced daily cycle. When the air is dry, sublimation efficiently cools the surface, reducing the probability of melting to occur (e.g. 13-14 January). If the air is moist, sublimation is reduced and melting occurs more readily with daytime peak values of $30 \mathrm{~W} \mathrm{~m}^{-2}$ (e.g. 8-10 January).

During clear conditions, noontime $\mathrm{R}_{\text {net }}$ reaches values up to $135 \mathrm{~W} \mathrm{~m}^{-2}$. This forces convection (negative $\mathrm{SHF}$ ) and significant sublimation (negative LHF), the latter reaching values between 30 and $50 \mathrm{~W} \mathrm{~m}^{-2}$. This strong sublimation prevents the occurrence of deeper convection at coastal sites compared to the interior (Van den Broeke 2005b, King et al. 2006). When melt occurs, $T_{s}$ can no longer increase, which reduces heat losses by $\mathrm{G}_{\mathrm{s}}$, SHF, $\mathrm{LHF}$ and $\mathrm{LW}_{\text {net }}$. Additional energy is invested in melting (M), which attains hourly mean values up to $90 \mathrm{~W} \mathrm{~m}^{-2}$, equivalent to a meltwater production of $\sim 1 \mathrm{~kg} \mathrm{~m}^{-2} \mathrm{hr}^{-1}$ (e.g. 3, 5 and 6 January).

Figure $5 \mathrm{~b}$ also demonstrates the major difficulty that arises when using observed $T_{\mathrm{s}}$ to detect melt events: even during strong, unequivocal melt conditions, observed $\mathrm{T}_{\mathrm{s}}$ may still be $<0^{\circ} \mathrm{C}$, which is the result of uncertainties in observed $\mathrm{LW}_{\text {out }}$. This stresses the advantage of using an SEB model to quantify melt from in situ data, even though the absolute modelled amount of melt and sublimation remains difficult to validate.

\section{Results: sublimation and melt}

\section{Surface sublimation}

Figure 6a shows the cumulative sublimation ( $\mathrm{LHF}<0$, green line), deposition (LHF $>0$, red line) and their sum (blue line) for the control run, in which snowdrift is not allowed. Sublimation averages $40 \mathrm{~kg} \mathrm{~m}^{-2} \mathrm{yr}^{-1}$, with little interannual variability $\left(\sigma=8 \mathrm{~kg} \mathrm{~m}^{-2} \mathrm{yr}^{-1}\right)$, while deposition averages $14 \mathrm{~kg} \mathrm{~m}^{-2} \mathrm{yr}^{-1}$, with similarly small interannual variability $\left(\sigma=3 \mathrm{~kg} \mathrm{~m}^{-2} \mathrm{yr}^{-1}\right)$. As shown in the previous section, sublimation is primarily temperature-driven, making it almost exclusively a summer phenomenon, while deposition

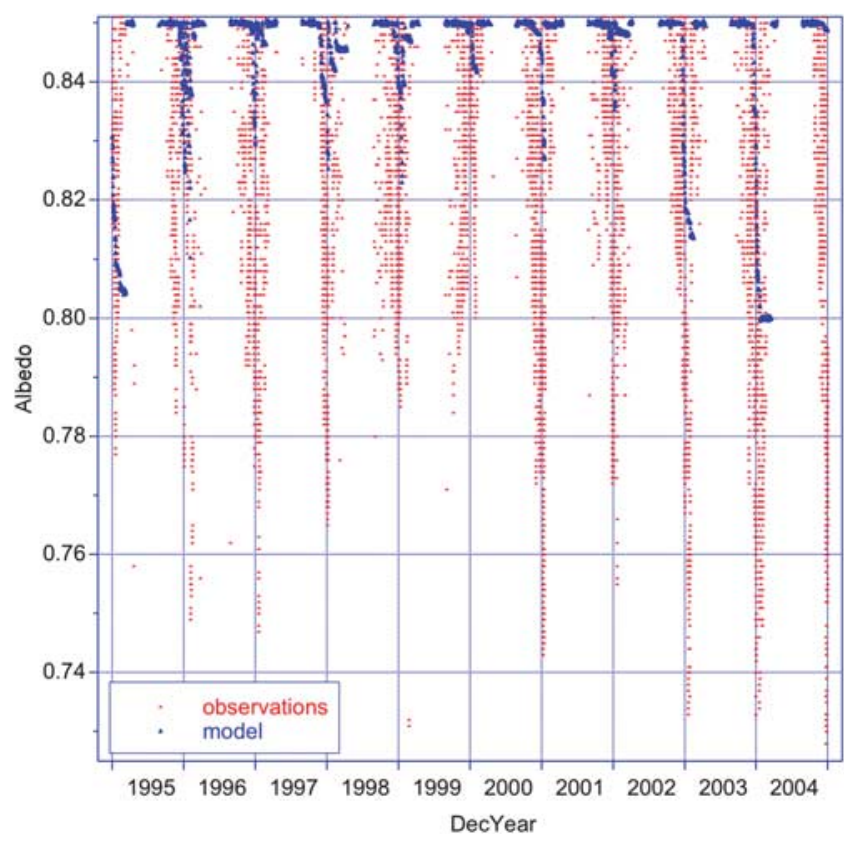

Fig. 7. Observed albedo at Neumayer (red symbols) and albedo from a regional climate model (blue symbols).

primarily occurs in winter. The net effect is that on average the turbulent moisture flux removes $26 \mathrm{~kg} \mathrm{~m}^{-2} \mathrm{yr}^{-1}$ from the surface. Schlosser \& Oerter (2002) used firn cores to determine the 1955-97 mean accumulation rate at Neumayer: $374 \mathrm{~kg} \mathrm{~m}^{-2} \mathrm{yr}^{-1}\left(\mathrm{~s}=87 \mathrm{~kg} \mathrm{~m}^{-2} \mathrm{yr}^{-1}\right)$. This suggests that, in the control run, $7 \%$ of the snowfall at Neumayer is removed from the surface by sublimation.

\section{Potential impact of snowdrift sublimation}

We investigate the potential impact of snowdrift sublimation by applying two bulk drifting snow sublimation formula of Déry \& Yau (2001) and Bintanja \& Reijmer (2001). We use a constant threshold friction velocity for drifting snow of $\mathrm{u}_{\mathrm{t}}=0.3 \mathrm{~m} \mathrm{~s}^{-1}$, which for the value of $\mathrm{z}_{0}$ adopted here corresponds to a threshold $10 \mathrm{~m}$ wind velocity of $7.8 \mathrm{~m} \mathrm{~s}^{-1}$. This wind speed is exceeded during $43 \%$ of the time at Neumayer. Using a more realistic, time-varying value of $u_{*}$ as in Gallée et al. (2001) is not possible owing to a lack of information about the state of the surface.

During snowdrift conditions, the near-surface air quickly becomes saturated (Déry et al. 1998) and under these conditions we assume surface sublimation to cease. Figure $6 \mathrm{~b}$ shows cumulative deposition (LHF $>0$, red line), surface sublimation (LHF $<0$, green line) and their sum (blue line) as well as cumulative snowdrift sublimation for the expression of Bintanja \& Reijmer (2001, black line) and the expression of Déry \& Yau (2001, orange line). Because of enhanced particle ventilation, snowdrift sublimation is clearly more effective than surface sublimation and, when averaged for both methods, equals $75 \mathrm{~kg} \mathrm{~m}^{-2} \mathrm{yr}^{-1}$. Surface moisture 

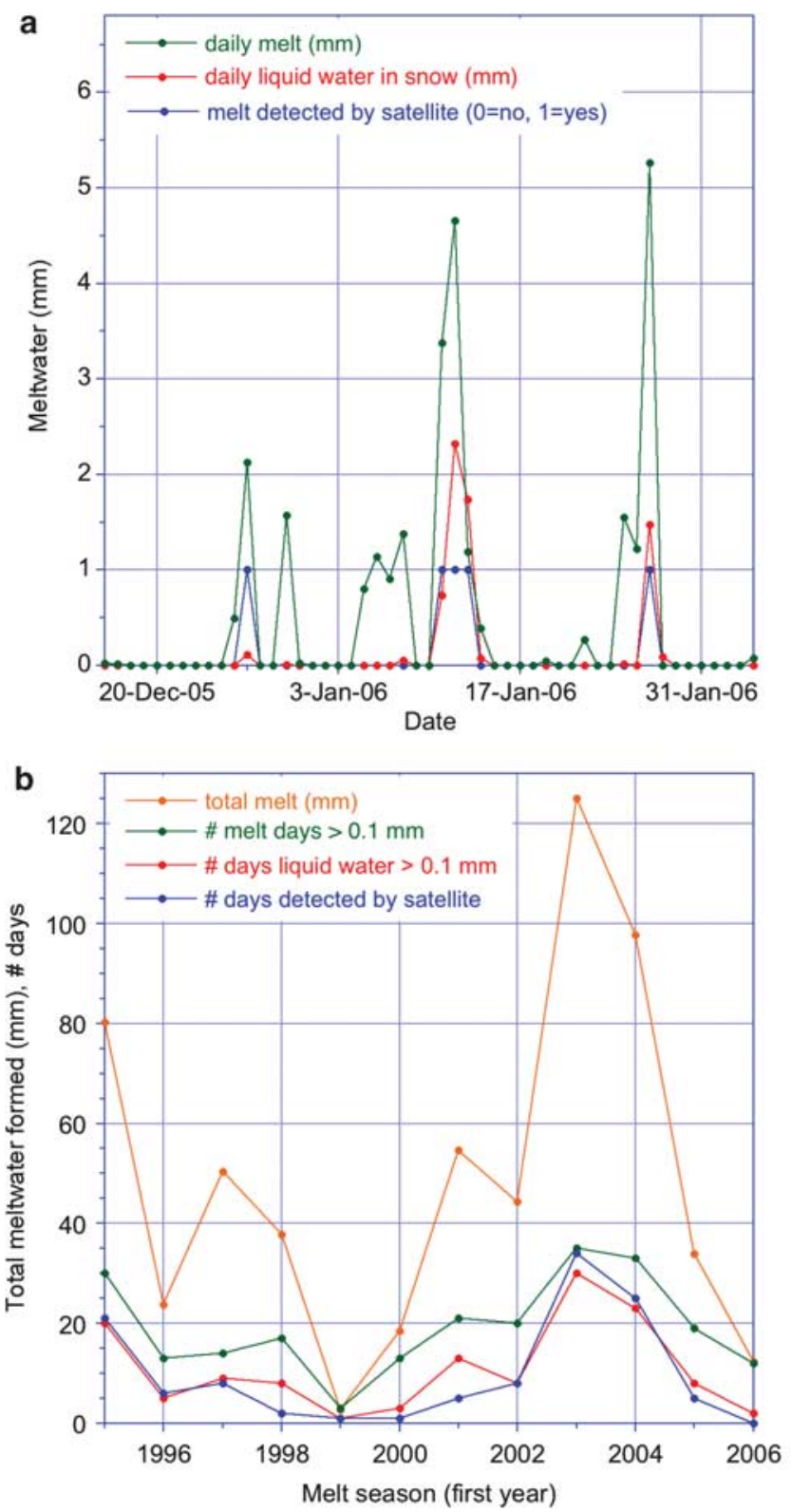

Fig. 8. a. Comparison of in situ calculated daily M (green line), LW amount (red line) and satellite-observed LW days (blue line) in the snowpack at Neumayer. b. 1994-2006 total in situ calculated summer M (orange line) and number of days per melt season with in situ daily $\mathrm{M}>0.1 \mathrm{~mm}$ (green line), $\mathrm{LW}>0.1 \mathrm{~mm}$ (red line) and $\mathrm{LW}$ detected by satellite (blue line).

exchange, which is set to zero during snowdrift, decreases to $17 \mathrm{~kg} \mathrm{~m}^{-2} \mathrm{yr}^{-1}$, deposition to $6 \mathrm{~kg} \mathrm{~m}^{-2} \mathrm{yr}^{-1}$, and the net effect to $11 \mathrm{~kg} \mathrm{~m}^{-2} \mathrm{yr}^{-1}$. Including snowdrift sublimation thus more than triples the total sublimation compared to the run without snowdrift ( $86 \mathrm{vs} 26 \mathrm{~kg} \mathrm{~m}^{-2} \mathrm{yr}^{-1}$ ), a stronger effect than was observed using AWS data further west where the effect was roughly a doubling (Van den Broeke et al. 2004b). If correct, this suggests that $17 \%$ of the snowfall at Neumayer is

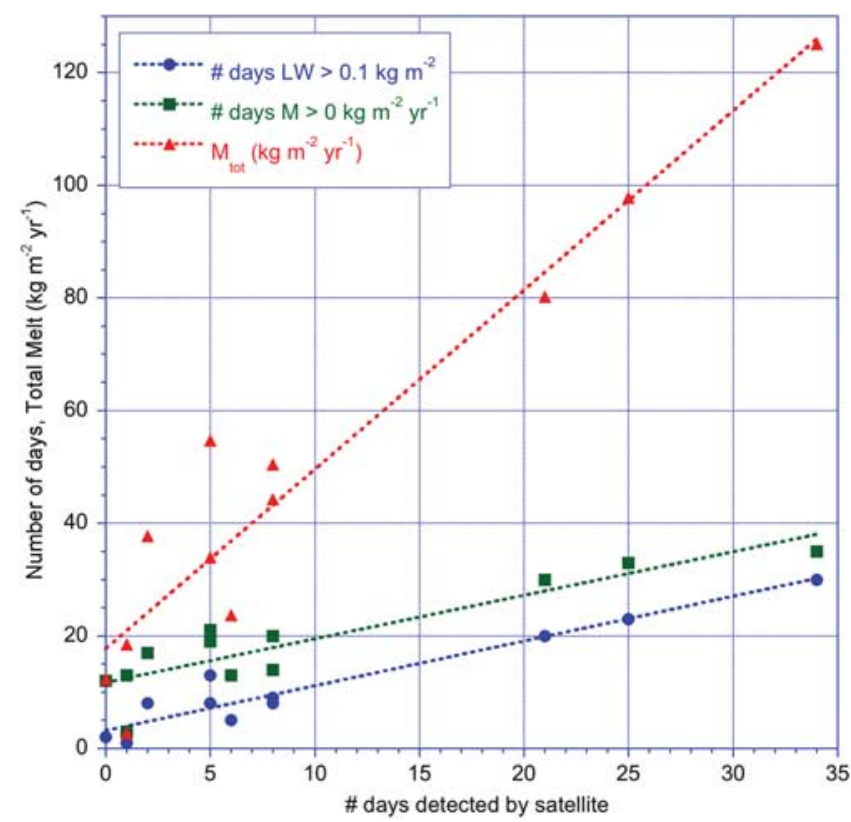

Fig. 9. Number of days per melt season with in situ LW $>0.1 \mathrm{~mm}$ (blue symbols), number of days with total daily $\mathrm{M}>0.1 \mathrm{~mm}$ (green line), and total summer $\mathrm{M}$ (red line) as a function of LW days as detected by satellite, at Neumayer.

removed from the surface by snowdrift sublimation and only $2 \%$ by surface sublimation.

We compare our results to those obtained by King et al. (2001) for Halley Station $\left(75^{\circ} 35^{\prime} \mathrm{S}, 26^{\circ} 25^{\prime} \mathrm{W}, 30 \mathrm{~m}\right.$ a.s.1.). Being situated on the Brunt ice shelf, Halley has a geographic setting comparable to Neumayer, albeit considerably further south. As a result, annual mean temperature $\left(-18.7^{\circ} \mathrm{C}\right)$ is $2.7^{\circ} \mathrm{C}$ lower than Neumayer, and $10 \mathrm{~m}$ wind speed $\left(6.5 \mathrm{~m} \mathrm{~s}^{-1}\right)$ $2.6 \mathrm{~m} \mathrm{~s}^{-1}$ lower. As a result, snowdrift frequency is about $25 \%$ at Halley, compared to $43 \%$ at Neumayer. King et al. (2001) estimated total annual sublimation at Halley to be $57 \mathrm{~kg} \mathrm{~m}^{-2}$, less than the $86 \mathrm{~kg} \mathrm{~m}^{-2} \mathrm{yr}^{-1}$ we found for Neumayer; the difference is fully accounted for by snowdrift sublimation ( $39 \mathrm{vs} 75 \mathrm{~kg} \mathrm{~m}^{-2} \mathrm{yr}^{-1}$ ). At both stations, sublimation removes a considerable fraction of the annual snowfall (10\% at Halley, $19 \%$ at Neumayer).

\section{Melt}

At Neumayer, as in most places in Antarctica, all meltwater refreezes in the cold snowpack, eliminating runoff (RU) as a contribution to the SSMB. Figure 6a (orange line) shows cumulative meltwater production from the SEB model. Seasonal meltwater production averages $47 \mathrm{~kg} \mathrm{~m}^{-2} \mathrm{yr}^{-1}$, but with very large interannual variability $\left(\sigma=36 \mathrm{~kg} \mathrm{~m}^{-2} \mathrm{yr}^{-1}\right)$ : the cold summer of 2000/01 experienced less than $3 \mathrm{~kg} \mathrm{~m}^{-2}$ of melt while the mild summer of 2003/04 had more than $125 \mathrm{~kg} \mathrm{~m}^{-2}$ of melt.

These numbers can be used to validate melt data from climate models and satellites. The black line in Fig. 6a 
Table II. Sensitivity of annual cumulative surface sublimation ( $\mathrm{SU}$ ), deposition (DE), snowdrift sublimation ( $\mathrm{SU} \mathrm{U}_{\mathrm{ds}}$ ) and melt (M) for indicated changes in $2 \mathrm{~m}$ temperature, relative humidity, $10 \mathrm{~m}$ wind speed and a doubling/halving of surface momentum roughness for the run without snowdrift (upper part) and run with snowdrift (lower part).

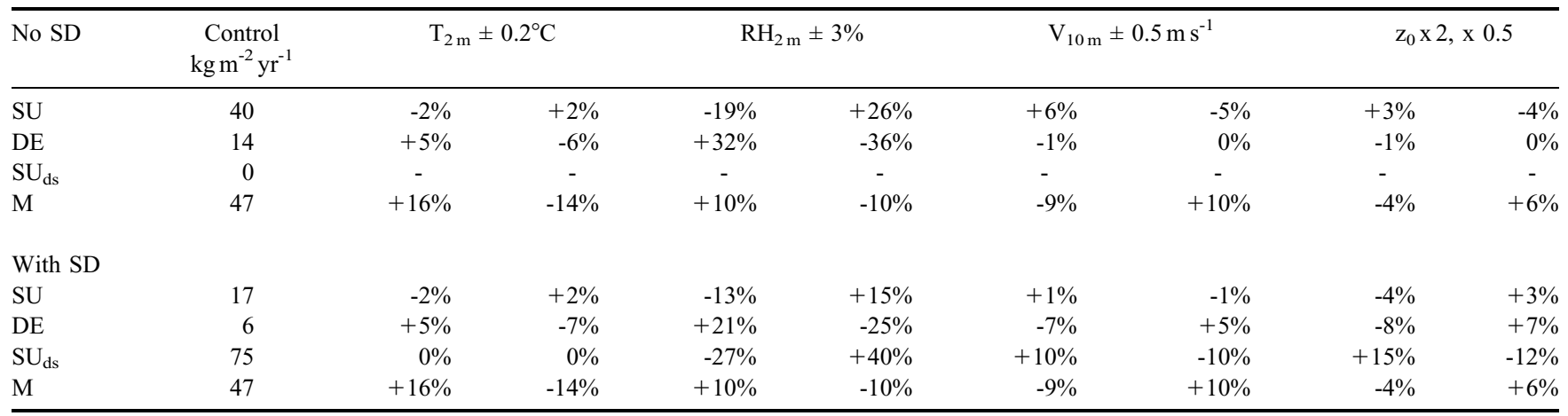

represents cumulative melt at Neumayer for the period 1994-2004 extracted from the regional atmospheric climate model RACMO2/ANT that was used for Fig. 1a. Interannual variability in $\mathrm{M}$ is well reproduced by the regional model, but modelled melt must be enhanced by a factor of $\sim 4$ to achieve quantitative agreement. A closer look at the SEB components reveals that the description of albedo in this particular version of the regional climate model does not reproduce the observed rapid albedo decrease when the surface is melting (Fig. 7). This demonstrates how in situ SEB modelling can be used to improve the representation of surface processes in atmospheric models.

Figure 8a compares the vertically integrated amount of liquid water in the snowpack at Neumayer (daily mean in millimetres, red line) with the satellite liquid water detection algorithm from Picard \& Fily (2006) for the summer of 2005/06. If we apply a threshold of $0.1 \mathrm{~mm}$, the SEB model and satellite agree on the five days where liquid water was present in the snow, suggesting that the satellite detection algorithm is very sensitive. The green line in Fig. 7a shows that meltwater production in excess of $0.1 \mathrm{~mm}$ occurred on as many as 15 days, but that on 10 of these days the meltwater instantaneously refroze so that no liquid water was present in the snow. Fig. 8b summarizes the number of days per summer that a) the total amount of meltwater formed exceeded $0.1 \mathrm{~mm}, \mathrm{~b}$ ) the daily average amount of vertically integrated liquid water exceeded $0.1 \mathrm{~mm}$, c) that the satellite detected liquid water in the snow, and d) the total amount of meltwater formed in that summer.

When we apply the $0.1 \mathrm{~mm}$ threshold to the full period 1994-2006, we find a good correlation $(r=0.96)$ between the number of satellite-detected liquid water days (Fig. 9, blue line) and days with liquid water from the SEB model (red line). We also find a good correlation $(r=0.90)$ between satellite-detected liquid water days and calculated melt days (green line), with an offset of about 12 days. Finally, a good correlation also exists between satellite-detected liquid water days and total melt (red line, $r=0.96$ ), but we expect that this relation is not universal for the whole of Antarctica. Nonetheless, combining satellite data with in situ melt rates shows promising results for future applications and may have the potential to derive melt rate from satellite products.

\section{Sensitivity tests}

To test the sensitivity of the modelled cumulative sublimation/deposition and melt to uncertainties in the observations, we performed 20 sensitivity runs in which a systematic bias with the magnitude of the instrumental error was prescribed in one of the input variables: $+/-0.2^{\circ} \mathrm{C}$ for temperature, $+/-3 \%$ for relative humidity, $+/-0.5 \mathrm{~m} \mathrm{~s}^{-1}$ for wind speed and a factor 2 for the surface momentum roughness $z_{0}$. The changes were applied to both the run with and without snowdrift. The results are summarized in Table II.

Sublimation and melt are moderately sensitive to temperature and wind speed $(-14 \%$ to $+16 \%)$. In the nonsnowdrift run, changing the surface roughness does not have a large impact on the cumulative mass fluxes $(-4 \%$ to $+6 \%$ ). This is partly caused by the compensating effect of the Andreas (1987) expression, which lowers $z_{h}$ when $z_{0}$ is increased. In the snowdrift run, the sensitivity to changes in $z_{0}$ are larger (up to $15 \%$ ), because it directly impacts on $u_{*}$ and hence the snowdrift frequency.

In the non-snowdrift run, the highest sensitivity (-36 to $+32 \%$ ) is found for cumulative sublimation and deposition when subjected to a $+/-3 \%$ change in relative humidity. This can be explained by the high average relative humidity at Neumayer, which in summer is only $12 \%$ and in winter only $4 \%$ below saturation. A systematic change of 3\% therefore represents a very large change in under-saturation, hence in cumulative sublimation and deposition. The sensitivity to changes in RH in the snowdrift run are also large, for similar reasons.

Melt is moderately sensitive (-9\% to $+16 \%)$ to changes in temperature, sublimation and wind speed. Figure $5 \mathrm{~b}$ showed that, untypically, both SHF and LHF are negative 
during typical melt conditions, indicating convection and sublimation. Increasing the $2 \mathrm{~m}$ temperature and humidity will decrease the surface-to-air temperature and humidity gradients, weakening convection and sublimation, which weakens surface cooling and increases the energy available for melt. Increasing the wind speed has the opposite effect, i.e. enhancing the turbulent fluxes and the associated cooling, decreasing melt. No changes in the sensitivity occur when snowdrift is allowed, indicating that snowdrift and melt do not occur simultaneously.

It should be noted that applying a random error as if it were a systematic error, as we do here, yields an upper estimate of the uncertainty. The actual uncertainty is random and its effect on cumulative mass fluxes therefore smaller. This is supported by the fact that in all the sensitivity tests, the model performance in reproducing the observed surface temperature deteriorated.

\section{Conclusions and future work}

We show that a surface energy balance model, driven by high-quality hourly observations from the Antarctic coastal station Neumayer, is capable of accurately reproducing observed surface temperatures. For this relatively cold and windy coastal site, surface sublimation is significant only in summer, when absorbed solar radiation heats the surface. Including a first order estimate of snowdrift sublimation more than triples the total (surface plus snowdrift) sublimation, indicating that this is potentially an important process for the mass balance of Antarctic ice shelves.

Surface melt does occur every summer at Neumayer, but with large interannual variations. The in situ melt that is calculated with the surface energy balance model can be used to validate and improve the representation of surface processes in climate models, e.g. the all-important meltalbedo feedback. A comparison of satellite-detected liquid water days and calculated in situ liquid water in the snow at Neumayer shows a high degree of correlation.

\section{References}

Anderson, E.A. 1976. A point energy and mass balance model of a snow cover. NOAA Technical Report, NWS19.

ANDERSON, P.S. 1994. A method for rescaling humidity sensors at temperatures well below freezing. Journal of Atmospheric and Oceanic Technology, 11, 1388-1391.

ANDREAS, E.L. 1987. A theory for the scalar roughness and the scalar transfer coefficients over snow and sea ice. Boundary-Layer Meteorology, 38, 159-184.

Bintanja, R. \& ReIJMER, C.H. 2001. A simple parameterization for snowdrift sublimation over Antarctic snow surfaces. Journal of Geophysical Research, 106, 31739-31748.

DÉrY, S.J. \& YAU, M.K. 2001. Simulation of blowing snow in the Canadian Arctic using a double-moment model. Boundary-Layer Meteorology, 99, 297.

DÉry, S.J., TAYlor, P.A. \& XIAO, J. 1998. The thermodynamic effects of sublimating, blowing snow in the atmospheric boundary layer. Boundary-Layer Meteorology, 89, 251-283.
Fahnestock, M.A., Abdalati, W. \& Shuman, C. 2002. Long melt seasons on ice shelves of the Antarctic Peninsula: an analysis using satellitebased microwave emission measurements. Annals of Glaciology, 34, 127-133.

Frezzotti, M., Pourchet, M., Flora, O., Gandolfi, S., Gay, M., Urbini, S., Vincent, C., Becagli, S., Gragnani, R., Proposito, M., Severi, M., Traversi, R., Udisti, R. \& Fily, M. 2004. New estimations of precipitation and surface sublimation in East Antarctica from snow accumulation measurements. Climate Dynamics, 23, 803-813.

FuJI, Y. 1979. Sublimation and condensation at the ice sheet surface of Mizuho Station, Antarctica. Antarctic Record, 67, 51-63.

Gallée, H., Guyomarch, G. \& Brun, E. 2001. Impact of snow drift on the Antarctic ice sheet surface mass balance: possible sensitivity to snow surface properties. Boundary-Layer Meteorology, 99, 1-19.

Gosink, J.P. 1989. The extension of a density current model of katabatic winds to include the effects of blowing snow and sublimation. Boundary-Layer Meteorology, 49, 367-394.

King, J.C., Anderson, P.S. \& Mann, G.W. 2001. The seasonal cycle of sublimation at Halley, Antarctica. Journal of Glaciology, 47, $1-8$.

King, J.C., Argentini, S.A. \& Anderson, P.S. 2006. Contrasts between the summertime surface energy balance and boundary layer structure at Dome C and Halley stations, Antarctica. Journal of Geophysical Research, 111, 10.1029/2005JD006130.

KönIG-Langlo, G. 1985. Roughness length of an Antarctic ice shelf. Polarforschung, 55, 27-32.

König-Langlo, G., King, J.C. \& Pettré, P. 1998. Climatology of the three Antarctic stations Dumont d'Urville, Neumayer and Halley. Journal of Geophysical Research, 103, 10935-10946.

Magand, O., Picard, G., Fily, M., Brucker, L. \& Genthon, C. 2008. Snow melting bias in microwave mapping of Antarctic snow accumulation. The Cryosphere, 2, 109-115.

Masson-Delmotte, V., Hou, S., Ekaykin, A., Jouzel, J., Aristarain, A., Bernardo, R.T., Bromwich, D., Cattani, O., Delmotte, M., Falourd, S., Frezzotti, M., Gallée, H., Genoni, L., Isaksson, E., Landais, A., Helsen, M.M., Hoffmann, G., Lopez, J., Morgan, V., Motoyama, H., Noone, D., Oerter, H., Petit, J.R., Royer, A., Uemura, R., Schmidt, G.A., Schlosser, E., Simoes, J.C., Steig, E.J., Stenni, B., Stievenard, M., van Den Broeke, M.R., van De Wal, R.S.W., van De Berg, W.J., VimeuX, F. \& White, J.W.C. 2008. A review of Antarctic surface snow isotopic composition: observations, atmospheric circulation and isotope modeling. Journal of Climate, 21, 3359-3387.

Morris, E.M. \& Vaughan, D.G. 2003. Spatial and temporal variation of surface temperature on the Antarctic Peninsula and the limit of viability of ice shelves. Antarctic Research Series, 79, 61-68.

Nghiem, S.V., Steffen, K., Neumann, G. \& Huff, R. 2008. Snow Accumulation and Snowmelt Monitoring in Greenland and Antarctica. In Tregoning, P. \& Rizos, C., eds. Dynamic planet: monitoring and understanding a dynamic planet with geodetic and oceanographic tools IAG Symposium Cairns, Australia 22-26 August. 2005. 10.1007/978-3540-49350-1_5, 31-38.

PiCARD, G. \& Fily, M. 2006. Surface melting observations in Antarctica by microwave radiometers: correcting 26 year-long timeseries from changes in acquisition hours. Remote Sensing of Environment, 104, 325.

Picard, G., Fily, M. \& Gallée, H. 2007. Surface melting derived from microwave radiometers: a climatic indicator in Antarctica. Annals of Glaciology, 46, 29-34.

Scambos, T., Hulbe, C. \& Fahnestock, M. 2003. Climate-induced ice shelf disintegration in the Antarctic Peninsula. Antarctic Research Series, 79, 79-92.

Schlosser, E. \& Oerter, H. 2002. Shallow firn cores from Neumayer, Ekströmisen, Antarctica: a comparison of accumulation rates and stableisotope ratios. Annals of Glaciology, 35, 91-96.

Sergienko, O. \& Macayeal, D.R. 2005. Surface melting on Larsen Ice Shelf, Antarctica. Annals of Glaciology, 40, 215. 
Takahashi, S., Naruse, R., Nakawo, M. \& Mae, S. 1988. A bare ice field in East Queen Maud Land, Antarctica, caused by horizontal divergence of drifting snow. Annals of Glaciology, 11, 156-160.

van De Berg, W.J., van Den Broeke, M.R. \& van Mejugahrd, E. 2006. Reassessment of the Antarctic surface mass balance using calibrated output of a regional atmospheric climate model. Journal of Geophysical Research, 111, 10.1029/2005JD006495.

VAN Den Broeke, M.R. 2005. Strong melting preceded collapse of Antarctic ice shelf. Geophysical Research Letters, 32, 10.1029/ 2005 GL023247.

van Den Broeke, M.R., Reimmer, C.H. \& van De Wal, R.S.W. 2004b. A study of the surface mass balance in Dronning Maud Land, Antarctica, using automatic weather stations. Journal of Glaciology, 50, 565-582.

van Den Broeke, M.R., van As, D., Reijmer, C.H. \& van De Wal, R.S.W. 2004a. Assessing and improving the quality of unattended radiation observations in Antarctica. Journal of Atmospheric and Oceanic Technology, 21, 1417-1431. van Den Broeke, M.R., van As, D., Reijmer, C.H. \& van De Wal, R.S.W. 2005a. Sensible heat exchange at the Antarctic snow surface: a study with automatic weather stations. International Journal of Climatology, 25, 1080-1101.

van Den Broeke, M.R., van De Berg, W.J., van Meijgaard, E. \& Reijmer, C.H. 2006. Identification of Antarctic ablation areas using a regional atmospheric climate model. Journal of Geophysical Research, 111, 10.1029/2006JD007127.

van Den Broeke, M.R., Reijmer, C.H., van As, D., van De Wal, R.S.W. \& Oerlemans, J. 2005b. Seasonal cycles of Antarctic surface energy balance from Automatic Weather Stations. Annals of Glaciology, 41, 131-139.

Vaughan, D.G., Marshall, G.J., Connolley, W.M., Parkinson, C., Mulvaney, R., Hodgson, D.A., King, J.C., Pudsey, C.J. \& Turner, J. 2003. Recent rapid regional climate warming on the Antarctic Peninsula. Climate Change, 60, 243-274.

Zwally, H.J. \& Fiegles, S. 1994. Extent and duration of Antarctic surface melting. Journal of Glaciology, 40, 463. 